\title{
KUALITAS SENSORIS DAGING ITIK AFKIR DENGAN LAMA PEMBERIAN TEPUNG DAUN ASAM GELUGUR (Garcinia Antroviridis) YANG BERBEDA DALAM RANSUM KOMERSIL
}

\section{SENSORY QUALITY OF MEAT OF CULLED DUCKS FED COMMERCIAL RATIONS CONTAINING GARCINIA (Garcinia Antroviridis) MEAL IN DIFFERENT LENGTH OF TIME.}

\author{
R Hardiyanto1a, E Dihansih, D Wahyuni
}

1Program Studi Peternakan Fakultas Pertanian Universitas Djuanda Bogor, Jl. Tol Ciawi No. 1, Kotak Pos 35 Ciawi, Bogor 16720.

aKorespondensi: Rico Hardiyanto, E-mail: ricohardiyanto@unida.ac.id

(Diterima oleh Dewan Redaksi: 27 Oktober 2021)

(Dipublikasikan oleh Dewan Redaksi: 31 oktober 2021)

\begin{abstract}
Compared to other animals, duck has some superiority as it is relatively more resistant to diseases and easier to raise. Garcinia leaf contains high hydroxycitric acid which is an organic acid known to have antilipidemic and antiobesity properties. This study was aimed at assessing the effects of the inclusion of garcinia leaf meal in rations in different length of time on sensory quality of meat of culled ducks. The study was conducted at the poultry farm of Department of Animal Science, Djuanda University, Bogor in 30 June to 4 August 2019. Sixteen culled female ducks were used in a completely randomized design with 4 treatments and 4 replicates. Four ducks were allocated to each treatment. Treatments consisted of the inclusion of $0 \%$ garcinia leaf meal in rations (R0, control) and $6 \%$ garcinia leaf meal in rations which were fed to the birds within 1 week (R1), 3 weeks (R2), and 5 weeks (R3). Data were subjected to a Kruskal Wallis test. Results of the hedonic test showed that the inclusion of garcinia leaf meal in rations gave significant effect $(\mathrm{P}<0.05)$ on meat taste but not $(\mathrm{P}>0.05)$ on meat aroma, tenderness, color, and juiceness. Meanwhile, results of panelis assessment in the hedonic quality test showed that significant differences $(\mathrm{P}<0.05)$ were found in meat tenderness, taste, and juiceness. It was concluded that duck meat color was improved with the inclusion of garcinia leaf meal in rations for 1 week and meat fishy smell was reduced with the inclusion of garcinia leaf meal in rations for 3 weeks.
\end{abstract}

Key words: sensory quality, culled duck, garcinia, hdroxycitric acid

\begin{abstract}
ABSTRAK
Itik memiliki keunggulan dibandingkan jenis ternak lainnya karena itik memiliki daya tahan terhadap penyakit cukup baik dan pemeliharaannya mudah. Kandungan daun asam gelugur berupa asam hidroksisitrat (HCA) merupakan asam organik utama berkhasiat sebagai antilipidemik dan antiobesitas. Penelitian bertujuan menguji lama pemberian tepung daun asam gelugur dalam ransum komersil terhadap kualitas sensoris daging itik afkir. Penelitian dilaksanakan di kandang unggas Program Studi Peternakan, Fakultas Pertanian, Universitas Djuanda Bogor pada tanggal 30 Juni 04 Agustus 2019. Ternak yang digunakan dalam penelitian 16 ekor itik Tegal afkir. Penelitian menggunakan rancangan acak lengkap (RAL) terdiri dari 4 perlakuan dan 4 ulangan, setiap perlakuan terdiri 4 ekor itik. Perlakuan penelitian ini adalah R0=0\% (kontrol), R1= pemberian 6\% selama 1 minggu, R2= pemberian $6 \%$ selama 3 minggu, R3= pemberian $6 \%$ selama 5 minggu. Data dianalisis menggunakan uji Kruskal wallis Hasil penelitian lama pemberian tepung daun asam gelugur dalam ransum komersil berpengaruh nyata $(\mathrm{P}<0,05)$ terhadap uji hedonik rasa dan tidak berpengaruh nyata $(\mathrm{P}>0,05)$ terhadap aroma, keempukan, warna, dan juiceness daging. Sedangkan penilaian panelis terhadap uji mutu hedonik berbeda nyata $(\mathrm{P}<0,05)$ terhadap aroma dan warna dan tidak berbeda
\end{abstract}


nyata $(\mathrm{P}>0,05)$ terhadap keempukkan, rasa, dan juiceness daging itik afkir. Kesimpulan Lama pemberian tepung daun asam gelugur 1 minggu pada ransum komersil dapat meningkatkan kesukaan terhadap rasa daging itik afkir.

Kata kunci : kualitas sensoris, itik afkir, asam gelugur, asam hidroksisitrat,

R hardiyanto, E Dihansih, D Wahyuni. Kualitas Sensoris Daging Itik Afkir dengan Lama Pemberian

Tepung Daun Asam Gelugur (Garcinia Antroviridis) yang Berbeda dalam Ransum Komersil.. Jurnal Peternakan Nusantara 7(2): 97-106

\section{PENDAHULUAN}

Itik merupakan salah satu potensi peternakan yang dapat diambil telurnya maupun dagingnya. Itik memiliki keunggulan dibandingkan dengan jenis ternak lainnya karena itik memiliki daya tahan terhadap penyakit yang cukup baik dan pemeliharaannya yang mudah. Menurut Direktorat Jendral Peternakan dan Kesehatan Hewan (2018) menunjukkan bahwa populasi ternak itik sebanyak 51.239.000 ekor dan produksi daging itik secara nasional pada tahun 2018 sebanyak 38.044 ton.

Daging itik menjadi sumber protein yang bernilai tinggi, oleh karena itu pengembangan pemeliharaan itik diarahkan kepada produksi daging sehingga mampu memenuhi permintaan konsumen. Namun, masalah utama yang sering dialami oleh peternak itik afkir adalah harga jual itik afkir yang rendah dipasaran. Faktor ini disebabkan oleh daging itik afkir yang mempunyai aroma amis dan mempunyai tekstur yang lebih alot. Aroma amis yang ditimbulkan dari daging itik berasal dari lemak subkutan yang cukup tinggi. Sehingga perlu diupayakan cara untuk mengurangi kadar lemak yang terdapat dalam daging itik untuk memperbaiki kualitas sensoris dari daging itik afkir. Memberikan feed additive alami adalah cara untuk menurunkan kadar lemak pada itik afkir sehingga, bau amis dan kualitas sensoris itik dapat lebih baik.

Tanaman asam gelugur (Garcinia antroviridis) memiliki kandungan zat aktif berupa alkaloid, flavonoid, saponin, tanin, karbohidrat dan protein juga asam-asam organik seperti asam tartarik, asam sitrat, dan juga asam malat. Daun asam gelugur memiliki kandungan di dalamnya berupa Hydroxycitrit Acid (HCA) yang dapat menghambat pertumbuhan lemak dan kolesterol. Asam hidroksitrat (HCA) merupakan asam organik utama yang berhasiat sebagai antilipidemik dan antiobesitas. Menurut (Meera et al 2013) bahwa HCA terdapat sekitar
20 - 30\% dalam buah Garcinia. Dengan demikian, cukup memungkinkan penggunaan tepung daun asam gelugur yang ditambahkan di dalam pakan komersil sebagai penyusun ransum itik afkir.

\section{MATERI DAN METODE}

\section{Materi}

Penelitian dilakukan selama 35 hari, mulai pada tanggal 30 Juni - 4 Agustus 2019, berlokasi di kandang unggas Program Studi Peternakan Fakultas Pertanian Universitas Djuanda Bogor.

Bahan yang digunakan dalam penelitian ini yaitu menggunakan itik lokal afkir yang berasal dari Cirebon sebanyak 16 ekor berjenis kelamin betina dan diberi perlakuan selama 35 hari. Bahan pakan yang digunakan pada penelitian ini adalah pakan komersil sebagai pakan dasar itik dengan tambahan tepung daun asam gelugur

Tabel 1 Kandungan Nutrisi dalam Pakan Gt-1

\begin{tabular}{lll}
\hline No & Komposisi & \multicolumn{1}{c}{$\begin{array}{l}\text { Kandungan } \\
\text { Nutrisi (\%) }\end{array}$} \\
\hline 1 & Protein & $16-18$ \\
2 & Lemak & $4-7$ \\
3 & Serat kasar & 7 \\
4 & Abu & 14 \\
5 & Air & 12 \\
6 & Ca & $3.5-4.0$ \\
7 & P & $0.7-0.9$ \\
\hline
\end{tabular}

Sumber : PT Shinta Prima Feedmill 2016

Kandang pada penelitian ini adalah kandang battery yang berjumlah 16 unit dengan panjang $40 \mathrm{~cm}$, lebar $35 \mathrm{~cm}$, tinggi $35 \mathrm{~cm}$ yang terbuat dari kawat besi. Alat yang digunakan pada penelitian ini yaitu tempat pakan, tempat minum, timbangan digital, kompor gas, oven, kompor gas, panci, blender, ember. 


\section{Perlakuan}

Penelitian ini menggunakan metode Rancangan Acak Lengkap (RAL) dengan 4 perlakuan dan 4 ulangan sehingga totalnya 16 unit satuan pengamatan, masing - masing unit terdiri atas 1 ekor.

R0 = Pakan komersil 100\%

$\mathrm{R} 1=$ Penambahan asam gelugur $6 \%$ selama 1 minggu

$\mathrm{R} 2=$ Penambahan asam gelugur $6 \%$ selama 3 minggu

R3 = Penambahan asam gelugur $6 \%$ selama 5 minggu

\section{Rancangan Percobaan}

Metode matematika penelitian sebagai beriku

$$
Y_{i j}=\mu+T_{i}+\varepsilon_{i j}
$$

Keterangan :

Yij = Nilai pengamatan dari perlakuan ke-i pada ulangan ke- $j$

$\mu=$ Nilai tengah umum

$\mathrm{T} i$ = Pengaruh lama pemberian tepung daun asam gelugur ke-i

$\varepsilon i j=$ Pengaruh galat percobaan pada lama pemberian tepung daun asam gelugur ke-i $(\mathrm{i}=$ $1,2,3)$ ada lama pemberian tepung daun asam pada ulangan ke-j. $(\mathrm{j}=1,2,3,4,5,6)$.

\section{Peubah yang Diamati}

Peubah yang diamati dalam penelitian ini yaitu uji sensoris yang dibagi menjadi 2 bagian yaitu uji hedonik dan uji mutu hedonik. Uji hedonik dilakukan untuk mengetahui kesukaan panelis terhadap produk. Panelis diminta untuk memberikan penilaian terhadap tingkat kesukaan dengan kisaran angka $1-5(1=$ sangat tidak suka, $2=$ tidak suka, $3=$ netral, $4=$ suka, $5=$ sangat suka). Parameter uji hedonik dan uji mutu hedonik meliputi aroma, warna, keempukan, rasa dan juiceness. Pada pengujian sampel diberi tiga angka sebagai kode sampel setiap perlakuannya yang ditempelkan di gelas plastik.
Tabel 2 skor penilaian uji mutu hedonik

\begin{tabular}{|c|c|c|}
\hline Peubah & Skor & Kriteria \\
\hline \multirow[t]{9}{*}{ Aroma } & 1 & Tidak \\
\hline & & beraroma amis \\
\hline & 2 & Sedikit \\
\hline & & beraroma amis \\
\hline & 3 & Cukup \\
\hline & & beraroma amis \\
\hline & 4 & $\begin{array}{l}\text { Beraroma } \\
\text { amis }\end{array}$ \\
\hline & 5 & Sangat \\
\hline & & beraroma amis \\
\hline \multirow[t]{5}{*}{ Keempukan } & 1 & Tidak empuk \\
\hline & 2 & Sedikit Empuk \\
\hline & 3 & Cukup empuk \\
\hline & 4 & Empuk \\
\hline & 5 & Sangat Empuk \\
\hline \multirow[t]{5}{*}{ Warna } & 1 & Sangat cerah \\
\hline & 2 & Cerah \\
\hline & 3 & Cukup cerah \\
\hline & 4 & Gelap \\
\hline & 5 & Sangat Gelap \\
\hline \multirow[t]{6}{*}{ Rasa } & 1 & Sangat tidak \\
\hline & 2 & enak \\
\hline & 3 & Tidak enak \\
\hline & 4 & Agak Enak \\
\hline & 5 & Enak \\
\hline & & Sangat enak \\
\hline \multirow[t]{8}{*}{ Juiceness } & 1 & Tidak \\
\hline & 2 & juiceness \\
\hline & 3 & Agak \\
\hline & 4 & juiceness \\
\hline & 5 & Cukup \\
\hline & & juiceness \\
\hline & & Juiceness \\
\hline & & $\begin{array}{l}\text { Sangat } \\
\text { juicness }\end{array}$ \\
\hline
\end{tabular}

\section{Analisis Data}

Data yang diperoleh dianalisis dengan sidik kruskall wallis dan jika perlakuan berpengaruh nyata terhadap peubah yang diamati maka analisis dilanjutkan dengan uji lanjut jarak ganda Duncan dengan menggunakan bantuan piranti program SPSS 16.

\section{Prosedur Pelaksanaan}

Kandang dan lingkungan di sekitar kandang harus dibersihan serta diberikan sumber penerangan. Tempat pakan dan tempat air minum diletakkan di setiap sekat kandang dan pada setiap kandang diberi alas dengan menggunakan karpet agar dapat menampung 
kotoran dari ternak. Peralatan kandang disiapkan dan berada di lingkungan kandang agar memudahkan dalam proses pemeliharaan ternak.

Daun asam yang digunakan dalam penelitian ini adalah daun asam gelugur (Garcinia antroviridis). Berikuit ini proses pembuatan tepung daun asam gelugur.

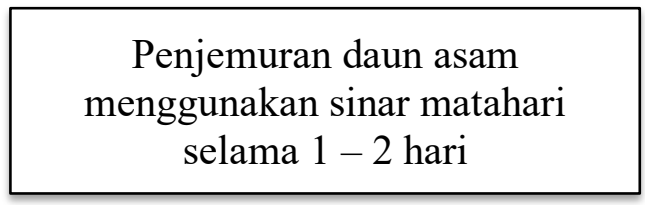

Pengeringan daun asam menggunakan oven $60^{\circ} \mathrm{C}$ selama 10 menit

Daun asam yang telah kering diblender hingga menjadi tepung

Itik yang digunakan berjumlah 16 ekor itik afkir dengan kondisi itik yang sehat, dan tidak cacat. Proses pertama yaitu melakukan proses penimbangan bobot badan awal pada itik sebelum diberi perlakuan dan diberikan identitas perlakuan pada kandang serta memberikan identitas perlakuan kepada itik yang diikatkan pada bagian kakinya. Penempatan kandang dan perlakuannya dilakukan secara acak.

Pemberian pakan dilakukan 2 kali sehari pada pukul 08.00 WIB dan pukul 16.00 WIB serta pemberian air minum yang bersifat adlibitum. Pemberian tepung daun asam gelugur yaitu dengan dicampur di dalam pakan komersil dan diaduk hingga tercampur. Pemberian pakan pada itik dapat dilihat pada Tabel 3.

Tabel 3 Jumlah pemberian pakan

\begin{tabular}{ccc}
\hline Waktu & $\begin{array}{c}\text { Tepung daun } \\
\text { asam gelugur } \\
\text { (gram) }\end{array}$ & $\begin{array}{c}\text { Pakan } \\
\text { komersil } \\
\text { (gram) }\end{array}$ \\
\hline Pagi & 4,5 & 75 \\
Sore & 4,5 & 75
\end{tabular}

\section{Total}

9

150

Proses pemotongan itik dilakukan pada $0,1,3$, dan 5 minggu dihitung dari awal perlakuan. Pemotongan itik dilakukan dengan syariat Islam dan memotong 3 bagian yaitu vena jugularis, esophagus dan arteri karotis yang terletak diantara leher dan kepala. Itik yang telah dipotong kemudian digantung agar darah keluar dan selanjutnya, memasukan itik ke dalam air panas dengan suhu $60-70^{\circ} \mathrm{C}$ yang bertujuan agar memudahkan dalam proses pencabutan bulu. Setelah itu, dilakukan proses pemotongan tubuh itik menjadi beberapa bagian dan pemisahan antara karkas dengan jeroan itik. kemudian, dilakukan proses pelepasan daging dengan tulang pada bagian dadan dan paha.

Sempel yang digunakan untuk uji organoleptik yaitu daging bagian paha. Setiap sempel sesuai dengan perlakuannya direbus menggunkan presto selama 5 menit. Daging dipotong dadu kemudian, disajikan di dalam gelas plastik transparan dengan diberi kode sebanyak 3 digit di masing-masing perlakuannya dan kode ditempelkan di gelas plastik.

Panelis yang digunakan pada uji organoleptik ini adalah panelis semi terlatih sebanyak 35 orang. Panelis akan diberikan pengarahan terlebih dahulu sebelum mengisi form yang sudah disediakan mengenai cara pengisian form uji organoleptik dan uji mutu hedonik oleh tim peneliti.

\section{HASIL DAN PEMBAHASAN}

\section{Uji Hedonik}

Penilaian yang dilakukan pada uji sensoris adalah uji hedonik dan uji mutu hedonik. Uji hedonik dilakukan untuk menilai tingkat kesukaan panelis terhadap sampel yang diberikan dengan kisaran angka $1-5(1=$ sangat tidak suka, $2=$ tidak suka, $3=$ netral, $4=$ suka, $5=$ sangat suka). Pengolahan data menggunakan uji Kruskul Wallis agar mengetahui tinggkat penerimaan dan penolakan panelis terhadap sampel yang diberikan. Nilai rataan uji hedonik daging itik lokal betina afkir dapat dilihat pada Tabel 4.

Tabel 4 Rataan Nilai Uji Hedonik Daging Itik Lokal Betina Afkir 


\begin{tabular}{llllll}
\hline & \multicolumn{5}{c}{ Perlakuan } \\
\cline { 2 - 5 } & R0 & R1 & R2 & R3 & $\begin{array}{c}\text { Rataa } \\
\text { n } \\
\text { Std }\end{array}$ \\
\hline Arom & $3,13 \pm$ & $3,60 \pm$ & $3,37 \pm$ & $3,53 \pm$ & $3,40 \pm$ \\
a & 0,94 & 0,86 & 0,89 & 0,90 & 0,89 \\
Keem & $3,33 \pm$ & $3,60 \pm$ & $3,47 \pm$ & $3,20 \pm$ & $3,40 \pm$ \\
pukan & 0,99 & 0,81 & 0,82 & 1,19 & 0,95 \\
Warna & $3,47 \pm$ & $3,43 \pm$ & $3,43 \pm$ & $3,40 \pm$ & $3,43 \pm$ \\
& 0,94 & 0,86 & 0,90 & 0,81 & 0,87 \\
Rasa & $3,13 \pm$ & $3,70 \pm$ & $3,40 \pm$ & $2,90 \pm$ & $3,28 \pm$ \\
& $0,97^{\text {a }}$ & $0,79^{\mathrm{b}}$ & $1,04^{\mathrm{b}}$ & $0,99^{\mathrm{a}}$ & 0,94 \\
Juicen & $3,20 \pm$ & $3,33 \pm$ & $3,23 \pm$ & $3,03 \pm$ & $3,19 \pm$ \\
ess & 0,89 & 1,09 & 0,82 & 0,93 & 0,93 \\
\hline
\end{tabular}

Keterangan : $\mathrm{R} 0=0 \%$ tepung daun asam gelugur, $\mathrm{R} 1=$ pemberian $6 \%$ tepung daun asam gelugur selama 1 minggu, R2 = pemberian $6 \%$ tepung daun asam gelugur selama 3 minggu, $\mathrm{R} 3=$ pemberian $6 \%$ tepung daun asam gelugur selama 5 minggu

Berdasarkan hasil dari analisis Kruskal Wallis dari setiap perlakuan menunjukkan bahwa lama pemberian tepung daun asam gelugur yang dicampur dalam pakan komersil memberikan pengaruh nyata $(\mathrm{P}<0,05)$ terhadap rasa tetapi tidak berpengaruh nyata $(P>0,05)$ terhadap aroma, keempukan, warna, dan juiceness. Berdasarkan hasil dari analisis Kruskal Wallis lama pemberian tepung daun asam gelugur pada peubah aroma tidak berpengaruh nyata $(\mathrm{P}>0,05)$. Penilaian panelis terhadap uji hedonik aroma daging dengan memberikan rataan nilai $3,40 \pm 0,89$. Nilai rataan pada aroma 3 yaitu netral tingkat kesukaan panelis terhadap aroma daging itik afkir. Hal ini menunjukkan bahwa lama pemberian perlakuan tidak mempengaruhi tingkat kesukaan panelis terhadap aroma daging. Menurut Setyaningsih et al (2010) bahwa bau atau aroma merupakan sifat sensoris yang paling sulit diklasifikasikan dan dijelaskan panelis karena ragamnya yang begitu besar dan tingkat sensitifitas organ pengindraan yang berbeda.

Lama pemberian tepung daun asam gelugur dengan hasil analisis Kruskal Wallis pada peubah keempukan pada daging itik afkir menunjukan bahwa tidak berpengaruh nyata $(P>0,05)$. Penilaian panelis terhadap uji hedonik keempukan daging itik afkir menghasilkan rataan $3,40 \pm 0,95$ Nilai rataan keempukan 3 menunjukkan bahwa tingkat kesukaan panelis terhadap keempukan daging itik afkir adalah netral. Keempukan daging sangat menentukan kualitas daging yang dapat mempengaruhi daya terima konsumen (Mattaputty daan Suryana 2010).
Berdasarkan hasil analisis Kruskal Wallis bahwa lama pemberian tepung daun asam gelugur pada peubah warna pada daging itik afkir tidak berpengaruh nyata $(P>0,05)$. Penilaian panelis terhadap uji hedonik warna pada daging itik afkir menghasilkan rataan 3,43 $\pm 0,87$. Nilai rataan warna 3 menunjukkan bahwa tingkat kesukaan panelis terhadap warna daging itik afkir adalah netral. Sedangkan berbeda pada hasil penelitian Siti et al (2016) yang menggunakan pakan dengan tambahan ekstrak daun pepaya terfermentasi level $16 \%$ pada kualitas daging unggas menunjukkan berbeda nyata $(\mathrm{P}<0,05)$ terhadap warna pada uji hedonik dengan rataan 3,07 yang berarti panelis tidak suka pada sampel daging unggas.

Lama pemberian tepung daun asam gelugur pada peubah rasa pada daging itik afkir menunjukkan bahwa memberikan pengaruh nyata $(\mathrm{P}<0,05)$ nilai tertinggi pada $\mathrm{R} 1$ dengan pemberian tepung daun asam gelugur sebanyak $6 \%$ selama 1 minggu mendapatkan nilai 3,70 dibandingkan pada perlakuan lainnya. Sehingga, menunjukkan bahwa panelis cendrung suka pada rasa sampel daging itik afkir.

Sependapat dengan hasil penelitian Dihansih et al (2017) bahwa penilaian panelis terhadap rasa menunjukkan berbeda nyata $(\mathrm{P}<0,05)$ pada perlakuan R1 yaitu penambahan larutan daun sirih 2,5\% panelis menilai suka terhadap sampel daging itik dengan posisi lebih rendah dari perlakuan lainnya.

Lama pemberian tepung daun asam gelugur pada peubah juiceness daging itik afkir menunjukkan bahwa tidak berpengaruh nyata $(\mathrm{P}>0,05)$. Penilaian panelis terhadap uji hedonik juiceness pada daging itik afkir menghasilkan rataan $3,19 \pm 0,93$. Nilai rataan juiceness menunjukkan bahwa tingkat kesukaan panelis terhadap juiceness daging itik afkir adalah netral. Juiceness dipengaruhi oleh adanya lemak intramuscular marbling sebagai stimulan terhadap salivasi dengan adanya kesan cairan yang dilepaskan selama pengunyahan dan salivasi yang diproduksi (Khaerina et al 2017).

\section{Uji Mutu Hedonik}

Uji mutu hedonik meliputi aroma, keempukan, warna, rasa dan juiceness dengan memberikan penilaian $1-5$ yang lebih spesifik terhadap daging (Tabel 5). Penilaian uji mutu hedonik diberikan panelis untuk memberikan nilai pada daging dengan menggunakan indera penciuman (hidung), pengecap rasa (lidah), dan 
penglihatan (mata). Hasil rataan uji mutu hedonik pada setiap perlakuan dapat dilihat pada Tabel 5. Secara keseluruhan perlakuan lama pemberian tepung daun asam gelugur berpengaruh nyata $(\mathrm{P}<0,05)$ pada peubah aroma dan warna.

Tabel 5 Rataan Uji Mutu Hedonik Daging Itik Lokal Betina Afkir dengan Lama Pemberian Tepung Daun Asam Gelugur

\begin{tabular}{llllll}
\hline \multirow{2}{*}{ Peubah } & \multicolumn{4}{c}{ Perlakuan } & \multicolumn{2}{c}{\begin{tabular}{c} 
Rataa \\
n \\
\cline { 2 - 5 }
\end{tabular}} & \multicolumn{1}{c}{ R0 } & \multicolumn{1}{c}{ R1 } & \multicolumn{1}{c}{ R2 } & R3 & Std \\
\hline Aroma & $2,90 \pm 1$, & $2,50 \pm 1$, & $2,30 \pm$ & $2,13 \pm$ & $2,45 \pm$ \\
& $12^{\mathrm{b}}$ & $02^{\mathrm{b}}$ & $1,06^{\mathrm{a}}$ & $1,17^{\mathrm{a}}$ & 1,09 \\
Keemp & $2,67 \pm 1$, & $3,00 \pm 0$, & $3,17 \pm$ & $2,67 \pm$ & $2,87 \pm$ \\
ukan & 06 & 95 & 0,91 & 1,27 & 1,04 \\
Warna & $2,67 \pm 1$, & $1,63 \pm 1$, & $1,87 \pm$ & $2,03 \pm$ & $2,05 \pm$ \\
& $40^{\mathrm{b}}$ & $13^{\mathrm{a}}$ & $0,94^{\mathrm{a}}$ & $1,22^{\mathrm{a}}$ & 1,17 \\
Rasa & $3,20 \pm 0$, & $3,67 \pm 0$, & $3,47 \pm$ & $3,47 \pm$ & $3,45 \pm$ \\
& 85 & 84 & 0,90 & 1,04 & 0,90 \\
Juicene & $2,47 \pm 1$, & $2,57 \pm 1$, & $2,50 \pm$ & $2,33 \pm$ & $2,46 \pm$ \\
ss & 20 & 22 & 1,07 & 1,18 & 1,16 \\
\hline
\end{tabular}

Keterangan : R0 $=0 \%$ tepung daun asam gelugur, R1 $=$ pemberian $6 \%$ tepung daun asam gelugur selama 1 minggu, $\mathrm{R} 2=$ pemberian $6 \%$ tepung daun asam gelugur selama 3 minggu, R3 = pemberian $6 \%$ tepung daun asam gelugur selama 5 minggu

\section{Aroma}

Berdasarkan hasil analisis Kruskal Wallis perlakuan lama pemberian tepung daun asam gelugur pada peubah aroma daging itik afkir yang menunjukkan hasil berbeda nyata $(\mathrm{P}<0,05)$. Pada Tabel 5 diketahui bahwa perlakuan R1, R2 dan R3 tidak berbeda nyata tetapi berbeda nyata dengan perlakuan R0. R0 pemberian pakan komersil 100\% tanpa tepung daun asam gelugur (kontrol) memberikan aroma pada daging itik afkir cendrung cukup beraroma amis. Sedangkan dengan daging itik afkir pada perlakuan lama pemberian tepung daun asam gelugur selama 1 minggu (R1), 3 minggu (R2), 5 minggu (R3), menghasilkan sedikit beraroma amis pada daging itik afkir. Hal ini disebabkan oleh kandungan di dalam daun asam gelugur yang mengandung antioksidan yang dapat menunda atau memperlambat reaksi radikal bebas oksidasi senyawa lipid sehingga dapat mengurangi bau amis pada itik. Sebagai pembanding pada hasil penelitian Dihansih et al (2017) dengan penambahan 7,5\% larutan daun sirih memiliki posisi lebih rendah dibanding perlakuan lainnya, tetapi masih memilki rataan yang sama dengan penilaian beraroma amis. Semakin bagus aroma daging maka semakin baik rasa daging yang dihasilkan (Fenita et al 2009).

\section{Keempukkan}

Berdasarkan hasil analisis Kruskal Wallis perlakuan lama pemberian tepung daun asam gelugur pada peubah keempukkan daging itik afkir memiliki rataan 2,87 dari seluruh perlakuan yang menunjukkan hasil yang tidak berbeda nyata $(\mathrm{P}>0,05)$. Nilai rataan menunjukkan bahwa keempukan pada sampel dikisaran sedikit empuk - cukup empuk. Berbeda dengan hasil penelitian Tugiyanti et al (2016) bahwa lama pemberian tepung daun sukun 9\% dalam pakan menghasilkan daging yang paling empuk. Menurut Reny (2009) bahwa faktor yang mempengaruhi keempukkan daging ada hubungannya dengan komposisi daging itu sendiri yaitu berupa tenunan pengikat, serabut daging, sel-sel lemak yang ada diantara serabut daging. Daging yang tidak berlemak menyebabkan nilai keempukkan daging rendah dan daging menjadi lebih keras (Hartono et al 2013).

\section{Warna}

Lama pemberian tepung daun asam gelugur berdasarkan hasil analisis Kruskal Wallis pada peubah warna daging itik afkir menunjukkan hasil yang berbeda nyata $(\mathrm{P}<0,05)$. Pada Tabel 5 diketahui bahwa perlakuaan R1, R2 dan R3 tidak berbeda nyata tetapi berbeda nyata dengan perlakuan R0. Pada R0 pemberian pakan komersil $100 \%$ tanpa tepung daun asam gelugur (kontrol) menunjukkan warna pada daging itik afkir putih kemerahan cendrung merah muda. Sedangkan pada daging itik afkir perlakuan lama pemberian tepung daun asam gelugur selama 1 minggu (R1), 3 minggu (R2), 5 minggu (R3), menghasilkan warna yang putih pucat sampai putih kemerahan. Faktor ini dikarenakan perbedaan warna yang diakibatkan oleh penurunan $\mathrm{pH}$ daging yang disebabkan oleh asam sitrat di dalam daun asam gelugur. Sebagai pembandingnya pada hasil penelitian Dihansih et al (2017) sampel daging yang menunjukkan warna semakin merah cerah yaitu 
penambahan 2,5\% larutan daun sirih dalam pakan dengan rataan nilai 2,13. Hal ini menunjukkan bahwa penggunaan larutan daun sirih dapat memberikan warna yang lebih cerah dengan taraf 2,5\%. Menurut Abustam (2012) bahwa penentuan warna daging adalah pigmen daging mioglobin, konsentrasinya dipengaruhi oleh beberapa faktor, seperti jenis ternak, bangsa jenis kelamin, umur, jenis otot, tingkat aktivitas otot, pakan, $\mathrm{Ph}$ dan oksigen.

\section{Rasa}

Hasil analisis Kruskal Wallis perlakuan lama pemberian tepung daun asam gelugur pada peubah rasa daging itik afkir memilki rataan 3,45 dari seluruh perlakuan yang menunjukkan hasil yang tidak berbeda nyata $(\mathrm{P}>0,05)$. Nilai rataan menunjukkan rasa sampel agak enak. Fakto-faktor yang mempengaruhi rasa diantaranya adalah pakan. Daun asam gelugur mengandung energi sebesar 73,64\% akan tetapi, tidak mempengaruhi rasa itik afkir dengan lama pemberian 1, 3, dan 5 minngu.

\section{Juiceness}

Berdasarkan hasil analisis Kruskal Wallis perlakuan terhadap lama permberian tepung daun asam gelugur pada peubah juiceness daging itik afkir memiliki rataan 2,46 dari seluruh perlakuan yang menunjukkan hasil yang tidak berbeda nyata $(\mathrm{P}>0,05)$. Nilai rataan menunjukkan bahwa sampel agak juiceness. Juiceness merupakan sifat sensoris berhubungan dengan tingkat kebasahan dari daging (Prayitno et al 2010). Daya ikat air (WHC) daging akan mempengaruhi seberapa besar air yang dapat dipertahankan di dalam produk sementara kadar lemak marbling akan membantu merangsang pembentukan saliva.

\section{KESIMPULAN DAN IMPLIKASI}

\section{Kesimpulan}

Pemberian tepung daun asam gelugur selama 1 minggu sudah dapt memperbaiki warna daging itik afkir sedangkan lama pemberian 3 minggu mampu menurunkan aroma amis pada daging itik afkir.

\section{DAFTAR PUSTAKA}

Abustam E. 2012. Ilmu Daging : Aspek produksi, kimia, biokimia, dan kualitas. Masagena Press, Makassar.

Agus Hadi Prayitno, Edi Suryanto, Zuprizal. 2010. Kualitas Fisik dan Sensoris Daging Ayam Broiler yang diberi Pakan dengan Penambahan Ampas Virgin Coconut Oil (VCO). Buletin Peternakan Vol. 34(1) : 55-63

Anam, C., N,S. Rahayu, Dan M, Baedowi. 2003. Aktivitas Enzim Bromelin Terhadap Mutu Fisik Daging. Jurnal Seminar Nasional Dan Pertemuan Tahunan Perhimpunan Ahli Teknologi Pangan Indonesia (PATPI) Peranan Industry dalam Pengembangan Produk Pangan Indonesia-Yogyakarta.

Badan Standardisasi Nasional. 2006. Petunjuk Pengujian Organoleptik dan atau Sensori. SNI 01 - 2346 - 2006. Standar Nasional Indonesia, Jakarta.

Chopra I. Robert, M. 2001. Tetracycline Antibiotic mode of action, application, moleculer biology, and epidemiology of bacterial resistances, Microbiology and Moleculer Biology. Review 62: 232-260.

Chung CS. 2006. Sweet and sour, the lovely gelugor. Gardenwise Vol. 2(6): 18-19.

Dihansih E, Handarini R, Haerina N. 2017. Kualitas Sensoris Daging dari Itik Lokal Jantan yang Diberi Larutan Daun Sirih dalam Pakan Komersil. Jurnal Peternakan Nusantara ISSN 2442-2541volume 3 nomor 1.

[Ditjen PKH] Direktorat Jendral Peternakan dan Kesehatan Hewan. 2018. Statistik Peternakan dan Kesehatan Hewan 2018. Direktorat Jendral Peternakan. Departemen Pertanian RI.

Fenita Y, Mega O, Dianti E. 2009. Pengaruh Pemberian Air Nanas (Ananas Cosumus) Terhadap Kualitas Daging Ayam petelur Afkir. Jurnal Sains Peternakan Indonesia. 4(1) :19783000.

Hartono E, Iriyanti N, Santosa R.S.S. 2013. Penggunaan Pakan Fungsional Terhadap Daya Ikat Air, Susut Masak, Dan Keempukan Daging Ayam Broiler. Jurnal Ilmiah Peternakan, 1(1):10-19

Hidayati NN, Enny YW, Isdadiyanto S. 2016. Perbandingan Kualitas Daging Itik Magelang, Itik Pengging dan Itik Tegal. Bioma: Berkala Ilmiah Biologi ISSN: 1410-8801, Vol 18 (1): 56 $-63$. 
Kementrian Pertanian. 2014. Plasma Nutfah Tanaman Asam Gelugur (Garcinia atroviridis Griff. Ex T. Anders.). Balai Penelitian Tanaman Buah Tropika, Sumatera Barat, Solok. No. 5 Mei 2014.

Ketaren, Prasetyo. 2007. Pengaruh pemberian pakan terbatas terhadap produktivitas itik silang mojosari $>$ Albio (MA): Masa pertumbuhan sampai betelur pertama. JITV. Vol 12 (1): 10 - 15.

Khaerina N, Dihansih D, Handarini R. 2017. Kualitas Sensoris Daging dari Itik Lokal Jantan (Ana Platyhrinchos) yang diberi Larutan Daun Sirih (Pipper Betle Linn) dalam Pakan Komersil. Jurnal Peternakan Nusantara ISSN 2442-2541 Volume 3 Nomor 1.

Lawrie, R.A. 2005. Meat Science. Edisi ke-5. Penerjemah : Aminudin Parakasi. UI Press. Jakarta.

Livianti R. 2008. Hubungan Antara Penilaian Cita Rasa Dengan Daya Terima Makan Siang yang Disajikan di SMA Pesantren Terpadu Hayatan Thoyyibah Kota Sukabumi Tahun 2008. Jurusan Gizi Politeknik Kesehatan Kemenkes Bandung. Bandung

Mackeen M, Muhammad M. 1998. BiossayGuided Isolation and Identification of Bioactive Compounds From Garcinia Atroviridis. University of Putra Malaysia, Malaysia.

Meera A, Prakash SJ, Prakash SO. 2013. Garcinia Indica for Metabolic Syndrome-a Review. Internasional Jornal of Experimental Pharmacology. Vol 3, Issue 2:57-60.

Mulyantini, NGA. 2010. Ilmu Manajemen Ternak Unggas. UGM Press. Yogyakarta.

Matitaputty PR, Suryana. 2010. Karakteristik Daging Itik dan Permasalahan serta Upaya Pencegahan off-flavor Akibat Oksidasi Lipid.Wartazoa Vol. 20 (3): 130 - 138.

Oteku IT, Igene JO, Yessuf IM. 2006. An assessment of the factors influencing the consumption of duck meat in Southern Nigeria. Pakistan J. Nutrition 5 (5) : 474-477.

Peraturan Menteri Pertanian. 2007. Pedoman Pengawasan Mutu Pangan. NOMOR : 65/Permentan/OT.140/9/2007.

Prasetyo L.Hardi, dan T. Susanti. 2005. Seleksi Awal Bibit Induk Itik Lokal. Laporan Bagian Proyek Rekayasa Teknologi Peternakan. Balai Penelitian Ternak, Bogor.

Purwati. 2007. The Effectivity of Polyprophylene Rigid AirTight Films In Inhibiting Quality
Changes of Chicken and Beef During Frozen Storage. Skripsi. IPB Bogor.

Rauf. 2009. Profil Arboretum USU. USU Press. Medan.

Reny, DT. 2009. Keempukkan Daging dan FaktorFaktor yang Mempengaruhinya. Balai Pengkajian Teknologi Pertanian. Lampung.

Setioko, A. R., L. H. Prasetyo, S. Sopiyana, T. Susanti, R. Hernawati dan S. Widodo. 2004. Koleksi dan Evaluasi karakterisasi biologok itik lokal dan Entog secara Exsitu. Laporan Hasilhasil Penelitian. Balitnak, Bogor.

Siti NW, Sukmawati IN, Ardika IN, Sumerta NM, Witariadi NN, Kusumawati C, Roni GK,. 2016. Pemanfataan Ekstrak Daun Pepaya Terfermentasi untuk Meningkatkan Kualitas Daging Ayam Kampung. Majalah Ilmiah Peternakan Vol 19 (2).

Sudiyono T.H. Purwatri. 2007. Pengaruh Penambahan Enzim Dalam Ransum Terhadap Persentase Karkas dan Bagian-Bagian Karkas Itik Lokal Jantan. Jurnal Pengembangan Peternakan Tropis. 32: 270-277.

Sudrajat, A. 2003. Pengaruh Temperatur dan Lama Pemasakan terhadap Karakteristik Fisik dan Organoleptik Daging Ayam Broiler. [Skripsi]. Yogyakarta: Fakultas Peternakan, Universitas Gadjah Mada.

Suprijatna, E. 2010. Strategi Pengembangan Ayam Lokal berbasis Sumber Daya Lokal dan Berwawasan Lingkungan. Prosiding Seminar Nasional Unggas Lokal ke IV. hal. 55 - 79.

Suradi, Kusmajadi. 2006. Perubahan Sifat Fisik Daging Ayam Broiler Post Mortem Selama Penyimpanan Temperatur Ruang. Jurnal Ilmu Ternak, Juni 2006 Vol. 6 No. 1:23-27.

Suryana. 2011. Karakterisasi Fenotipik dan Genetik Itik Alabio Dan Pemanfaatannya di Kalimantan Selatan Secara Berkelanjutan. Disertasi. Sekolah Pascasarjana Institut Pertanian Bogor, Bogor. .

Susilorini, T.E. 2010. Budi Daya 22 Ternak Potensial. Jakarta: Penebar Swadaya.

Susiwi S. 2009. Penilaian Organoleptik. Universitas Pendidikan Indonesia.

Theron MM, Lues JFR, 2011. Organic Acids and Food Preservation. CRC Press. New York.

Tugiyanti E, Sulistyawan IH, Setianto NA, Susanti E, Mastuti S. 2016. Pengaruh Pemberian Tepung Daun Sukun ke dalam Pakan Terhadap Kualitas Daging Itik Jantan Umur 9 Minggu. Seminar Nasional Peternakan 2, 
Fakultas Peternakan Universitas Hasanuddin Makassar.

Warris. 2000. Meat science an introductory text. CABI Publishing, Bristol.

Winarno FG. 2002. Kimia Pangan dan Gizi. PT. Gramedia Pustaka Utama. Jakarta.

Winarno FG. 2004. Kimia Pangan. PT. Gramedia Pustaka Utama. Jakarta.

Zulfahmi M, Pramono YB, Antonius H. 2013. Pengaruh Marinasi Ekstrak Kulit Nenas (Ananas Comocus L. Merr) pada Daging Itik Tegal Betina Afkir Terhadap Kualitas Keempukan dan Organoleptik. Jurnal Pangan dan Gizi. Vol. 4 No. 8 
